\title{
Taurine Modulates Hyperglycemia-Mediated Oxidative Stress and Protects Hepatocytes in Experimental Diabetes
}

\author{
Nema Mohamed ${ }^{1}$, Horeya Abdel Gawad ${ }^{2}$, Farozia Mousa ${ }^{3}$, Rhagad Shihab ${ }^{4}$ \\ ${ }^{1,2,3}$ Department of Zoology, Alexandria University, Alexandria, Egypt \\ ${ }^{4}$ Department of Biology, College of Science for Women, Baghdad University, Iraq
}

\begin{abstract}
The present study was conducted to investigate the beneficial effects of taurine (TAU) on glucose and lipid metabolism and its positive roles in the correction of oxidative stress diabetes-related complications in STZ diabetic rats. Diabetic rats showed significant $(P<0.05)$ increase in the levels of glucose, HbAlc, AST, ALT, LDH, liver and kidney weights, urea, uric acid, creatinine and significant decrease in the levels of body and pancreas weights, insulin, pancreatic amylase, hexokinase, liver and muscle glycogen, total protein, albumin, antioxidant enzymes and HDL-C. Also, higher levels of cholesterol, TG, total lipids, LDL-C and MDA were noticed in diabetic rats. The taurine administration (50 $\mathrm{mg} / \mathrm{kg}$ ) showed antihyperglycemic effect as indicated by reduced glucose levels, HbAlc and improved insulin level and carbohydrate hydrolyzing enzymes. In addition, taurine supplementation normalized liver function and inhibited lipid prfile alterations while, kidney weight, urea, creatinine, uric acid, total protein and albumin levels were partially improved. The obtained results revealed that taurine exhibited an inhibitory effect on oxidative stress indices (MDA) and partially improved antioxidantlevels. Taurine could have potential as a pharmaceutical drug for diabetes mellitus (DM). Additional study is needed to investigate whether taurine has the same beneficial effects in human diabetic patients.
\end{abstract}

Keywords: Diabetes, taurine, glycosylated hemoglobin, insulin, rats.

\section{Introduction}

Diabetes is a complex, chronic illness that requires consistent medical care and treatment to help control blood sugar levels and prevent acute or long-term complications of the disease, such as kidney failure and amputations [1]. It is growing with a fast rate and is likely to affect 340 million people, which is expected to reach 552 million in 2030 [2], consequently, diabetes presents a major challenge to healthcare systems around the world.

Concerning the terrible increase in the worldwide diabetic population, there is a need for new therapies that are more effective with minimum adverse effects [3]. Many oral antihyperglycemic agents have significant side effects and some are ineffective in chronic diabetic patients [4]. In spite of the introduction of hypoglycemic drugs, diabetes and related complications continue to be a major medical problem [5]. Thus, there is an increasing need of new natural antihyperglycemic products especially nutraceuticals with less side effects, safe, and high antihyperglycemic potential.

Taurine (2-aminoethylsulphonic acid, TAU) is a nonprotein amino acid present in nearly all animal tissues and the most plentiful free intracellular amino acid in human cells [6]. The main source of taurine in vivo is dietary intake and biosynthesis. Endogenous production of taurine is insufficient, so that it needs to be provided through the diet. Taurine, the end product of L-cysteine metabolism has shown capacity in protecting from various free radicals associated with pathological conditions. It exerts anti-inflammatory, neuromodulator [7], immunomodulator [8] and it has been used as a treatment for alcoholism [9]. In addition, this conditionally essential aminoacid is also an authenticated potent scavenger of the hydroxyl radical, a membrane stabilizing agent and as a detoxifying agent [10]. Taurine is now thought to play a more important role in human nutrition, and dietary intake of taurine has been linked to several beneficial health outcomes in various diseases and medical conditions [11].

In the present study, we have evaluated taurine antidiabetic activity and its positive roles in the correction of oxidative stress diabetes-related complications in STZ diabetic rats.

\section{Materials and Methods}

\subsection{Animals}

Male Wistar rats (200-250 g), were obtained from the Faculty of Medicine, Alexandria University, Egypt. The animals were held in an air conditioned room $\left(22 \pm 3^{\circ} \mathrm{C}\right)$ with $55 \pm 5 \%$ humidity and a 12-hour light/dark cycle. They were fed with a standard diet and had free access to water. The local committee approved the design of the experiments and the protocols were carried out according to the guidelines of the National Institutes of Health (NIH).

\subsection{Chemicals}

Streptozotocin (STZ) and taurine (TAU) were purchased from Sigma-Aldrich Chemical Company (St. Louis, MO, USA). All other chemicals and reagents used were of analytical grade.

\subsection{Induction of Diabetes:}

Diabetes was induced by administration of a single intraperitoneal injection of $40 \mathrm{mg} / \mathrm{kg}$ body weight STZ which was prepared freshly. Three days after administration of STZ, 


\section{International Journal of Science and Research (IJSR) \\ ISSN (Online): 2319-7064}

Index Copernicus Value (2013): 6.14 | Impact Factor (2014): 5.611

serum glucose levels were determined. Only rats with fasting blood glucose over $250 \mathrm{mg} / \mathrm{dl}$ [13] were considered diabetic and included in the experiments.

\subsection{Experimental Design}

40 male rats were randomly divided into four groups (10 rats/group) as follows:

Group 1: Animals of this group were injected with $0.1 \mathrm{ml}$ of citrate buffer ( $\mathrm{pH}: 4.5$ ).

Group 2: Animals of this group were injected intraperitoneally with TAU at dose $50 \mathrm{mg} / \mathrm{kg}$ body weight for 15 days [14].

Group 3: Animals of this group were injected intraperitoneally with STZ at single dose 40 $\mathrm{mg} / \mathrm{kg}$ body weight [15].

Group 4: Animals of this group were injected intraperitoneally with STZ at a single dose (40 $\mathrm{mg} / \mathrm{kg}$ body weight) and after 3 days they were injected with TAU at a dose (50 $\mathrm{mg} / \mathrm{kg}$ body weight) for 15 days.

At the end of experiment body, liver, kidney and pancreas weights were recorded.

\subsection{Preparation of Plasma}

The heparinized blood samples were centrifuged at $3000 \mathrm{~g}$ for $15 \mathrm{~min}$. Plasma was separated and then stored at -20 ${ }^{\circ} \mathrm{C}$ until biochemical analysis.

\subsection{Preparation of Liver and Pancreas Homogenates:}

Whole tissues of the liver and pancreas were obtained by dissection, cleaned from adhering matters, washed with physiological saline. Then a portion of the liver and pancreas tissues from each rat was minced and homogenized in 5-10 $\mathrm{ml}$ cold buffer (i.e. $50 \mathrm{mM}$ potassium phosphate, $\mathrm{pH} 7.4,1 \mathrm{mM}$ ethylene diamine tetracetic acid, EDTA). Homogenates were centrifuged at $10,000 \times \mathrm{g}$ for - 20 minutes at $4{ }^{\circ} \mathrm{C}$ and the clear supernatants were separated for antioxidant determination and lipid peroxidation.

\subsection{Biochemical Studies}

Glucose level was measured as reported by Trinder [16] method. Glycosylated hemoglobin (HbAlc) was estimated by fast ion - exchange resin separation method [17]. Insulin, pancreatic amylase and hexokinase were determined according to the methods of Finlay and Dillard [18], Pulse and Schmidt [19] and Gubern et al. [20], respectively. Liver and muscle glycogen contents were determined by the method of Huijing [21]. Enzymatic activities of aspartate transaminase (AST), alanine transaminase (ALT) and lactate dehydrogenase (LDH) were determined according to Tietz [22] and Henry (1974) [23] methods. Total protein was determined by Gornall et al. [24] method. Determination of total cholesterol, low density lipoprotein (LDL) and high density lipoprotein (HDL) were estimated by the methods of Allain et al. [25] and Burstein et al. [26]. Triglycerides and total lipids were determined according to Wahlefeld and Bergmeyer [27] and Frings et al. (28) methods, respectively. Urea, creatinine and uric acid were estimated by using the method of Newman and Price [29]. Pancreas and liver lipid peroxidation end products, MDA, were measured according to Ohkawa et al. [30] method. Also, the levels of glutathione (GSH) [31] and the activities of the antioxidant enzymes, including superoxide dismutase (SOD) [32], the catalase enzyme (CAT) [323] and glutathione peroxidase (GPx) [34] were assayed in liver and pancreas homogenates.

\subsection{Data and Statistical Analysis}

Data were expressed as mean \pm standard error. The data were analyzed using SPSS Statistical Package Version 19 (Chicago, IL, USA). Statistical comparisons between all groups were performed by using ANOVA-1. The significant differences were considered at $\mathrm{P}<0.05$.

\section{Results}

\subsection{Effect of taurine on the body, liver, kidney and pancreas weights in STZ induced diabetic rats:}

The body weight of diabetic rats was significantly decreased from basal value of the control group. With respect to the liver and kidney weight changes, significant increase was observed in STZ treated rats in comparison with the control one. On the other hand, pancreas weight was decreased in the STZ group as compared with the control group. The TAU supplementation ameliorated these changes as compared to the STZ group (Table 1).

Table 1: Effect of taurine supplementation on body, liver, kidney and pancreas weights in STZ induced diabetic rats.

\begin{tabular}{|c|c|c|c|c|}
\hline \multirow{2}{*}{ Parameters } & \multicolumn{4}{|c|}{ Experimental groups } \\
\cline { 2 - 5 } & Control & TAU & STZ & TAU+STZ \\
\hline Body weight & $203.00 \pm$ & $210.00 \pm$ & $172.60 \pm$ & $200.25 \pm$ \\
$(\mathrm{g})$ & 15.556 & 5.944 & $22.130^{\mathrm{a}}$ & $10.210^{\mathrm{b}}$ \\
\hline Liver weight & $6.110 \pm$ & $6.042 \pm$ & $7.630 \pm$ & $6.01 \pm$ \\
(g) & 0.735 & 0.695 & $1.506^{\mathrm{a}}$ & $1.712^{\mathrm{b}}$ \\
\hline Kidney weight & $0.619 \pm$ & $0.614 \pm$ & $0.868 \pm$ & $0.703 \pm$ \\
(g) & 0.127 & 0.175 & $0.173^{\mathrm{a}}$ & $0.124^{\mathrm{ab}}$ \\
\hline Pancreas weight & $0.422 \pm$ & $0.423 \pm$ & $0.319 \pm$ & $0.425 \pm$ \\
(g) & 0.064 & 0.061 & $0.097^{\mathrm{a}}$ & $0.067^{\mathrm{b}}$ \\
\hline
\end{tabular}

-Values represent the mean \pm SE of 10 individual rats. -a-means significantly different from the control group.

-b-means significantly different from the streptozotocin treated group. $-\mathrm{P}>0.05$.

\subsection{Effect of taurine on serum glucose, insulin, HbAlc, $\alpha$ - amylase, hexokinase and glycogen in STZ-diabetic rats}

Injection of male rats with STZ induced a significant increase in glucose and HbAlc levels. The administration of TAU resulted in a significant reduction of glucose and $\mathrm{HbA} 1 \mathrm{c}$ levels as compared to STZ treated group. STZ administration was associated with a highly significant decrease in insulin, $\alpha$ amylase and hexokinase levels as compared to the control group. Administration of TAU improved the insulin, $\alpha$ amylase and hexokinase levels in comparison with the STZ group (Table 2). Also, supplementation of TAU improved the decreased liver and kidney glycogen in STZ group. 


\section{International Journal of Science and Research (IJSR) \\ ISSN (Online): 2319-7064 \\ Index Copernicus Value (2013): 6.14 | Impact Factor (2014): 5.611}

Table 2: Effect of taurine supplementation on serum glucose, insulin, HbA1c, $\alpha$ - amylase, hexokinase and glycogen in STZ-diabetic rats

\begin{tabular}{|c|c|c|c|c|}
\hline Parameters & \multicolumn{4}{|c|}{ Exerimental groups } \\
\hline & Control & TAU & STZ & $\begin{array}{c}\text { TAU+ST } \\
\text { Z }\end{array}$ \\
\hline Glucose & 89.200 & 90.000 & 321.500 & $94.600 \pm$ \\
$(\mathrm{mg} / \mathrm{dl})$ & \pm & \pm & \pm & $5.588^{\mathrm{b}}$ \\
& 9.935 & 4.546 & $6.520^{\mathrm{a}}$ & \\
\hline Insulin & $2.920 \pm$ & $2.680 \pm$ & $1.25 \pm$ & $1.860 \pm$ \\
$(\mathrm{mlU} / \mathrm{ml})$ & 0.879 & 0.936 & $0.918^{\mathrm{a}}$ & $0.783^{\mathrm{b}}$ \\
\hline HbA1c & $5.180 \pm$ & $5.140 \pm$ & $9.125 \pm$ & $7.260 \pm$ \\
$(\%)$ & 0.766 & 1.197 & $0.793^{\mathrm{a}}$ & $1.443^{\mathrm{b}}$ \\
\hline Amylase & $8.280 \pm$ & $8.940 \pm$ & $4.100 \pm$ & $6.880 \pm$ \\
(U/L) & 2.184 & 2.721 & $2.974^{\mathrm{a}}$ & $2.660^{\mathrm{b}}$ \\
\hline Hexokinas & 11.880 & $10.60 \pm$ & $4.375 \pm$ & $9.180 \pm$ \\
e (U/L) & \pm & 3.52 & $1.621^{\mathrm{a}}$ & $1.911^{\mathrm{b}}$ \\
& 2.875 & & & \\
\hline Liver & 215.80 & 200.00 & $68.60 \pm$ & $144.40 \pm$ \\
glycogen & \pm & \pm & $7.0894^{\mathrm{a}}$ & $11.6086^{\mathrm{b}}$ \\
(mg/g & 6.1757 & 6.4884 & & \\
tissue) & & & & \\
\hline Kidney & 156.20 & 152.00 & $73.60 \pm$ & $122.00 \pm$ \\
glycogen & \pm & \pm & $7.3864^{\mathrm{a}}$ & $7.1861^{\mathrm{b}}$ \\
(mg/g & 10.7256 & 4.7497 & & \\
tissue) & & & & \\
\hline
\end{tabular}

-Values represent the mean \pm SE of 10 individual rats.

-a-means significantly different from the control group.

-b-means significantly different from the streptozotocin treated group. $-\mathrm{P}>0.05$

\subsection{Effect of taurine on AST, ALT, LDH, total protein and albumin levels in STZ-diabetic rats}

AST, ALT and LDH levels were significantly increased in STZ treated rats as compared to the control value. The coadministration of TAU with STZ resulted in significant reduction in liver function enzymes as compared to STZ treated group. Concentrations of total protein and albumin were significantly decreased after STZ injection compared to the control. Administration of TAU followed STZ injection for 15 days improved the total protein and albumin levels (Table 3 ).

Table 3: Effect of taurine supplementation on AST, ALT, $\mathrm{LDH}$, total protein and albumin levels in STZ-diabetic rats.

\begin{tabular}{|c|c|c|c|c|}
\hline \multirow{2}{*}{ Parameters } & \multicolumn{4}{|c|}{ Experimental groups } \\
\cline { 2 - 5 } & Control & TAU & STZ & TAU+STZ \\
\hline AST & $61.600 \pm$ & $66.200 \pm$ & $156.750 \pm$ & $96.600 \pm$ \\
$(\mathrm{U} / \mathrm{dl})$ & 9.072 & 19.854 & $17.233^{\mathrm{a}}$ & $16.003^{\mathrm{b}}$ \\
\hline ALT & $32.800 \pm$ & $31.200 \pm$ & $88.250 \pm$ & $55.800 \pm$ \\
$(\mathrm{U} / \mathrm{dl})$ & 8.643 & 15.595 & $9.811^{\mathrm{a}}$ & $15.287^{\mathrm{b}}$ \\
\hline LDH & $116.400 \pm$ & $113.000 \pm$ & $255.500 \pm$ & $191.800 \pm$ \\
$(\mathrm{U} / \mathrm{dl})$ & 28.059 & 29.155 & $18.141^{\mathrm{a}}$ & $17.167^{\mathrm{b}}$ \\
\hline Total protein & $6.900 \pm$ & $6.720 \pm$ & $4.925 \pm$ & $6.660 \pm$ \\
(g/dl) & 0.778 & 0.581 & $0.222^{\mathrm{a}}$ & $0.647^{\mathrm{b}}$ \\
\hline Albumin & $3.660 \pm$ & $3.400 \pm$ & $2.225 \pm$ & $3.120 \pm$ \\
(g/dl) & 0.541 & 0.539 & $0.602^{\mathrm{a}}$ & $0.952^{\mathrm{b}}$ \\
\hline
\end{tabular}

-Values represent the mean \pm SE of 10 individual rats.

-a-means significantly different from the control group.

-b-means significantly different from the streptozotocin treated group. $-\mathrm{P}>0.05$

\subsection{Effect of taurine on serum lipid profile in STZ-diabetic} rats

STZ administration was associated with a significant increase in lipid profile [Total cholesterol (TC), total lipid (TL), triglycerides (TG), low density lipoproteins (LDL-C)] in the plasma except high density lipoprotein (HDL-C) as shown in table 5. TAU treatment in combination with STZ improved the hyperlipidemia of diabetic rats. Also, TAU treatment in combination with STZ improved the decrease in HDL (Table 4).

Table 4: Effect of taurine supplementation on serum lipid profile in STZ-diabetic rats.

\begin{tabular}{|c|c|c|c|c|}
\hline \multirow{2}{*}{ Parameters } & \multicolumn{4}{|c|}{ Experimental groups } \\
\cline { 2 - 5 } & Control & TAU & STZ & TAU+STZ \\
\hline Total Cholesterol & $133.60 \pm$ & $129.60 \pm$ & $266.00 \pm$ & $174.40 \pm$ \\
(mg/dl) & 23.298 & 32.921 & $58.839^{\mathrm{a}}$ & $19.715^{\mathrm{b}}$ \\
\hline Total lipid & $457.00 \pm$ & $464.20 \pm$ & $1045.00 \pm$ & $631.40 \pm$ \\
(mg/dl) & 54.240 & 86.459 & $224.767^{\mathrm{a}}$ & $74.36^{\mathrm{b}}$ \\
\hline Triglyceride & $82.40 \pm$ & $84.00 \pm$ & $234.00 \pm$ & $124.00 \pm$ \\
(mg/dl) & 15.678 & 14.000 & $67.735^{\mathrm{a}}$ & $25.49^{\mathrm{b}}$ \\
\hline HDL-C & $50.80 \pm$ & $49.80 \pm$ & $31.25 \pm$ & $44.40 \pm$ \\
(mg/dl) & 8.349 & 4.382 & $7.932^{\mathrm{a}}$ & $10.286^{\mathrm{b}}$ \\
\hline LDL-C & $66.32 \pm$ & $63.00 \pm$ & $187.95 \pm$ & $106.00 \pm$ \\
(mg/dl) & 21.180 & 31.664 & $48.638^{\mathrm{a}}$ & $12.033^{\mathrm{b}}$ \\
\hline
\end{tabular}

-Values represent the mean \pm SE of 10 individual rats. -a-means significantly different from the control group.

-b-means significantly different from the streptozotocin treated groups $-\mathrm{P}>0.05$

\subsection{Effect of taurine on urea, creatinine and uric acid levels in STZ-diabetic rats}

STZ administration was associated with a highly significant increase in urea, creatinine and uric acid levels as shown in table 6. Injection of TAU following STZ administration partially improved these elevations since there was a significant difference between values of this group and the control group (Table 5).

Table 5: Effect of taurine supplementation on urea, creatinine and uric acid levels in STZ-diabetic rats.

\begin{tabular}{|c|c|c|c|c|}
\hline \multirow{2}{*}{ Parameters } & \multicolumn{4}{|c|}{ Exerimental groups } \\
\cline { 2 - 5 } & Control & TAU & STZ & TAU+STZ \\
\hline Urea & 28.000 & 28.400 & 38.250 & 33.200 \\
(mg/dl) & \pm 6.892 & \pm 7.569 & $\pm 8.921^{\mathrm{a}}$ & $\pm 6.791^{\mathrm{ab}}$ \\
\hline Creatinine & 0.498 & 0.444 & 1.300 & 0.704 \\
(mg/dl) & \pm 0.151 & \pm 0.129 & $\pm 0.392^{\mathrm{a}}$ & $\pm 0.142^{\mathrm{ab}}$ \\
\hline Uric acid & 1.500 & 1.400 & 4.000 & 2.340 \\
(mg/dl) & \pm 0.604 & \pm 0.604 & $\pm 2.309^{\mathrm{a}}$ & $\pm 0.627^{\mathrm{ab}}$ \\
\hline
\end{tabular}

-Values represent the mean \pm SE of 10 individual rats. -a-means significantly different from the control group. -b-means significantly different from the streptozotocin treated group. $-\mathrm{P}>0.05$

\subsection{Effect of taurine on malondialdhyde (MDA) in streptozotocin-diabetic rats}

Administration of TAU together with STZ partially improved the increased levels of MDA in liver and pancreas as compared to the untreated group (Table 6). 


\section{International Journal of Science and Research (IJSR) \\ ISSN (Online): 2319-7064}

Index Copernicus Value (2013): 6.14 | Impact Factor (2014): 5.611

Table 6: Effect of taurine supplementation on malondialdhyde (MDA) in streptozotocin-diabetic rats.

\begin{tabular}{|c|c|c|c|c|}
\hline \multirow{2}{*}{ Parameters } & \multicolumn{4}{|c|}{ Experimental groups } \\
\cline { 2 - 5 } & Control & TAU & STZ & TAU+STZ \\
\hline MDA liver & 15.000 & 16.000 & 47.000 & 32.333 \\
(nmol/mg) & \pm 3.606 & \pm 6.000 & $\pm 11.136^{\mathrm{a}}$ & $\pm 7.506^{\mathrm{ab}}$ \\
\hline MDA & 15.333 & 15.333 & 67.000 & 39.333 \\
pancreas & \pm 5.132 & \pm 2.887 & $\pm 9.165^{\mathrm{a}}$ & $\pm 8.505^{\mathrm{ab}}$ \\
(nmol/mg) & & & & \\
\hline
\end{tabular}

-Values represent the mean \pm SE of 10 individual rats.

-a-means significantly different from the control group.

-b-means significantly different from the streptozotocin treated groups.

\subsection{Effect of taurine on some antioxidant enzymes activities in liver and pancreas homogenates}

A significant decrease was observed in liver and pancreas antioxidant enzyme levels (SOD, GPX and CAT) in rats treated with STZ comparing with the control group. TAU treatment in combination with STZ partialy improved these decreased levels as compared with untreated diabetic rats (Figures 1, 2 and 3). $-\mathrm{P}>0.05$

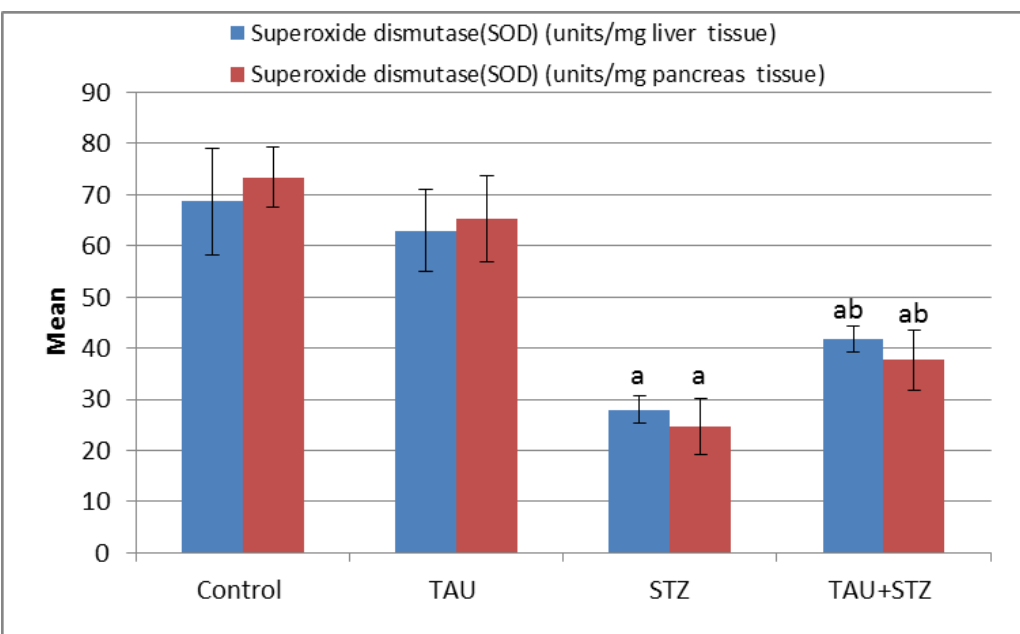

Figure 1: Effect of taurine supplementation on superoxide dismutase (SOD) activities in liver and pancreas homogenates

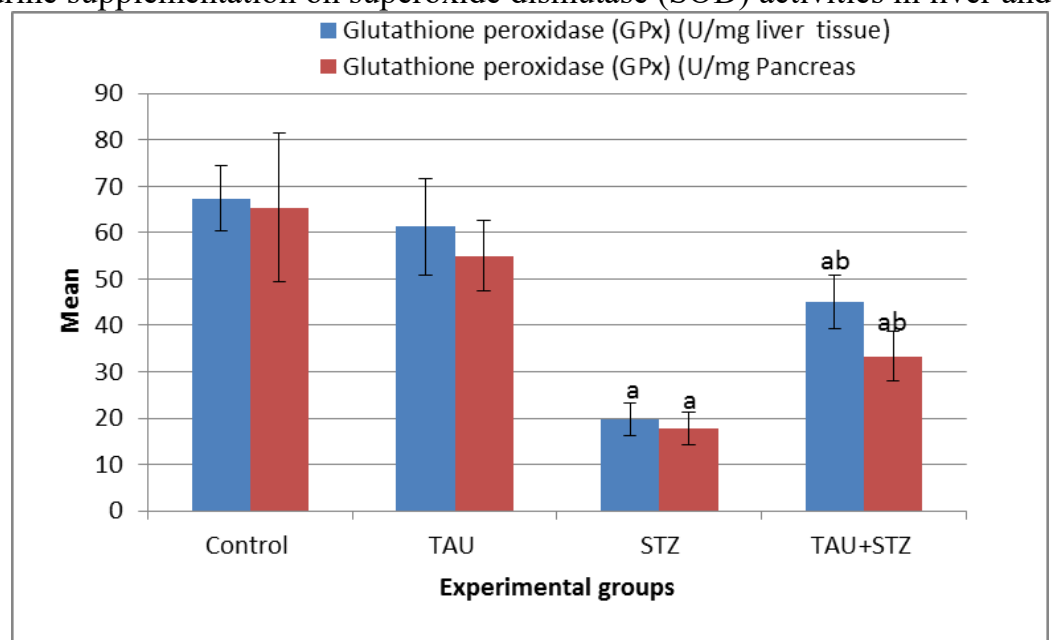

Figure 2: Effect of taurine supplementation on glutathione peroxidase (GPX) activities in liver and pancreas homogenates

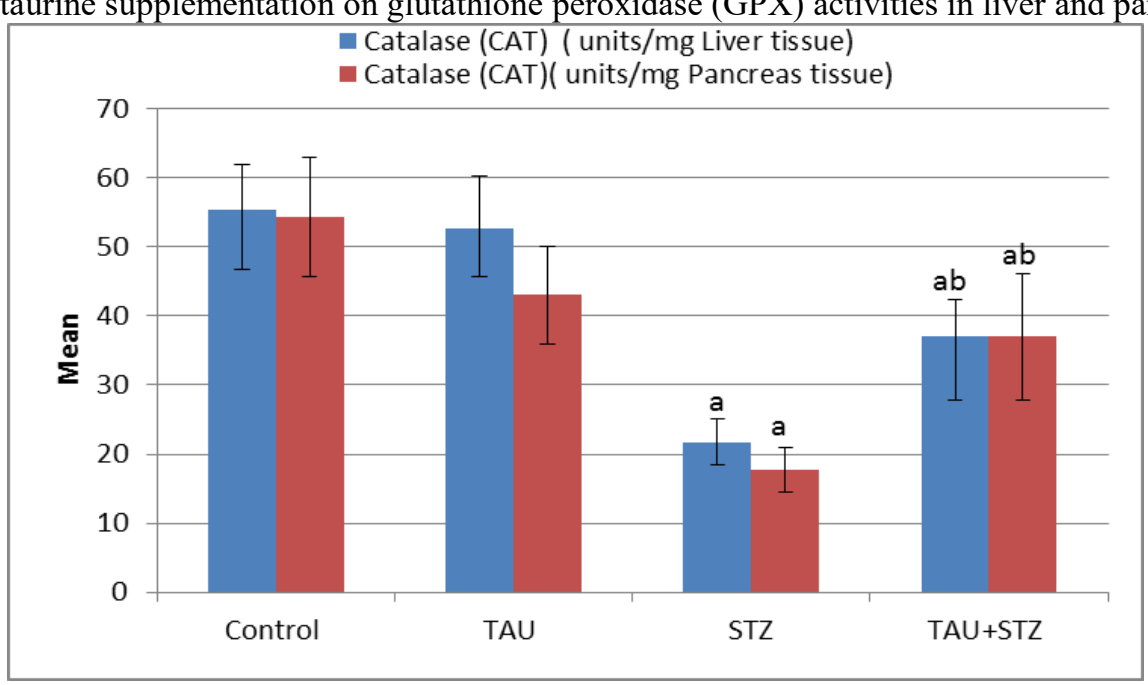

Figure 3: Effect of taurine supplementation on Catalase (CAT) activities in liver and pancreas homogenates

Volume 5 Issue 1, January 2016

www.ijsr.net 
International Journal of Science and Research (IJSR)

ISSN (Online): 2319-7064

Index Copernicus Value (2013): 6.14 | Impact Factor (2014): 5.611

\subsection{Effect of taurine supplementation on non enzymatic antioxidant in liver and pancreas:}

GSH of liver and pancreas in STZ treated group were decreased as compared with the control group. Administration of TAU together with STZ partially improved these decreased levels as compared to STZ group (Figure 4).

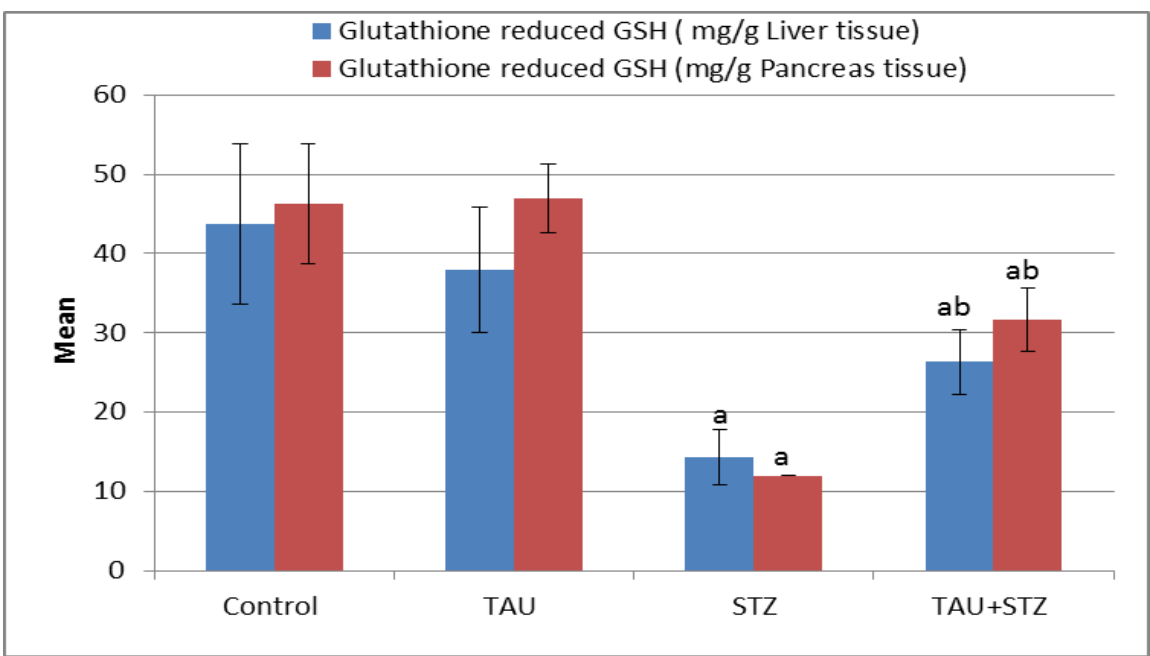

Figure 4: Effect of taurine supplementation on glutathione reduced (GSH) in liver and pancreas homogenates

\section{Discussion}

The reduction in the body weight of the diabetic animals has been linked to degradation of structural proteins and muscle wasting due to unavailability of carbohydrate for utilization as an energy source. The body weight loss came accordance with the finding of Oyedemi et al. [35]. Lee et al. [36] found that the animal treated with STZ appeared ill-looking with the loss of their body weights.

The increase in the kidney weight may be due the cellular autophagy in the cells of proximal and distal convoluted tubules that due to the hypertrophic growth of kidney cortex [37] or may be due to tubulointerstitial fibrosis and fibronectin in diabetic rats [38]. The increment of liver weight may be due to increase triglyceride accumulation leading to enlarged liver which could be due to the increased influx of fatty acids into the liver induced by hypoinsulinemia and the low capacity of excretion of lipoprotein secretion from the liver [37]. The decrease in the pancreas weight agrees with the results of Heidari et al. [39] who stated that the loss of pancreas weight may be due to destruction of pancreatic islets and insulinproducing cells. The amelioration effect of taurine on body, liver, kidney and pancreas weights suggesting that TAU exhibits a protective effect against cellular- stress as reported by Ito et al. [12].

The mechanism by which STZ brings about its diabetic state included selective destruction of pancreatic insulin secreting $\beta$-cells, which make cells less active, leading to poor glucose utilization by tissues. The present hyperglycemia was found consistent with the results obtained by Anusuya et al. [40]. Glycosylated hemoglobin (HbAlc) is useful in the demonstration of glycemic control in patients with DM [41]. HbA1c level was found to be increased in the untreated diabetic rats [42]. It is produced by non-enzymatic condensation of glucose molecules with free amino acid on the globin component of hemoglobin [43].
It seemed that the initial drop in the $\alpha$-amylase activity may be interpreted by the impaired pancreatic exocrine secretion due to a decrease in the insulin stimulatory action [44]. The present finding came accordance with Burski et al. [45] who stated that $\alpha$-amylase activity in the rabbit serum, within the first three weeks of diabetes, was dropped to the levels below the half of the values noted in healthy controls. Hexokinase plays a central role in the maintenance of glucose homeostasis. The hexokinase activity was found to be decreased in diabetic rats which may be due to insulin deficiency [46]. The observed decrease in hepatic and muscle glycogen may be due to insufficient insulin and inactivation of the glycogen synthetase system in the diabetic state [47].

Taurine exerts hypoglycemic effects by regulating the expression of genes required for the glucose-stimulated insulin secretion and enhancing insulin action [48], as well as by facilitating the interaction of insulin with its receptor [9]. On the other hand, TAU enhances glycogenesis, glycolysis and glucose oxidation [49]. Taurine has also demonstrated to have hypoglycemic effects producing a decrease in the concentrations of glucose and fructosamine as well as an increase in the contents of insulin, C-peptide, and glycogen in the liver [50]. Kim et al. [51] reported that taurine ameliorated hyperglycemia by improving insulin sensitivity in OLETF rats with long-term diabetes. Decreased HbA1c levels in the TAU treated diabetic rats could be due to an improvement in insulin secretion from the remnant pancreatic $\beta$-cells in diabetic rats, consequently, resulting in improvement in glycemic control [47].

The present elevations of AST, ALT and LDH observed in diabetic rats agree with Kumarappan et al. [52]. The increase in AST and ALT may be due to leakage of these enzymes from the liver cytosol into the blood stream and/or change in the permeability of liver cell membranes take place [53]. Ahn et al. [54] suggested that serum ALT concentrations were independently associated with type 2 diabetes in both sexes. They stated that increased AST, ALT, and GGT levels reflect 


\section{International Journal of Science and Research (IJSR) \\ ISSN (Online): 2319-7064 \\ Index Copernicus Value (2013): 6.14 | Impact Factor (2014): 5.611}

an excess deposit of fat in the liver, a condition known as non-alcoholic fatty liver disease (NAFLD).

The present study disclosed a significant decrease in total protein concentration as a result of insulin deficiency which leads to increased catabolism of protein. The increased rate of proteolysis leads to elevated concentration of amino acids in plasma that serve as precursors for hepatic and renal glyconeogenesis, which further contributes to the hyperglycemia seen in DM [55]. Also, this decrease in total protein might be due to microproteinuria which was an important clinical marker of diabetic nephropathy. The present result coincided with the findings of Daisy et al. [56].

The reversal of ALT and AST activities in TAU treated diabetic rats towards near normalcy indicate the liver protective nature. These results were in agreement with Turner and Wass [57] who reported marked reductions in proteinuria in STZ-induced diabetic rats with decreased renal lipid peroxidation after oral supplementation of taurine. Zhang et al. [58] reported that TAU improved hepatic enzymes in hepatotoxicity.

Hyperlipidemia is a relatively common problem in patients with poorly controlled diabetes mellitus [59] and coexists with hyperglycemia and is characterized by increased levels of cholesterol, triglycerides and phospholipids, and also changes in lipoproteins. The diabetic hyperlipidemia was attributed to the disturbance of hormonal regulation of glucose metabolism. The present hyperlipidemia was in line way with a previous investigation of Bagri et al. [60].

The hypolipidemic effect of TAU was partly due to the inhibition of cholesterol absorption in the intestine or increasing the conversion of cholesterol to bile acid. Futhermore, it has been suggested that TAU may be responsible for the increase of HDL or end balance of the serum lipoprotein fractions containing cholesterol [61]. Moreover, it is likely possible that drinking TAU increases serum cholesterol clearance and decreases hepatic TC level in high-fat/cholesterol dietary hamsters, which may be up due to regulations of the LDL receptor, thus increasing fecal TC and bile acids output [62]. Yang et al. [63] stated that TAU could alleviate blood lipids and hepatic damage induced by a high-fat/cholesterol-dietary diet. The data of Saleh [43] indicated that the treatment of diabetic rats with TAU induced decrease in lipid profile except HDL-cholestrol.

The increase in urea and creatinine levels, recorded in STZ-diabetic rats, may be due to increase protein catabolism, glomerular injury and renal dysfunction. This finding was found in agreement with the results of Prangthip et al. [64]. Taurine administration prevented the occurrence and development of diabetic nephropathy by decreasing blood glucose, improving lipid metabolism and glomerular basement membrane metabolism [65]. Taurine in the drinking water of diabetic rats helped them recover from kidney damage [60]. The effects of taurine on diabetic nephropathy showed the results of improvements in oxidative stress [66].
The present study revealed that the elevation in MDA level might be a reflection of a decrease in enzymatic and nonenzymatic antioxidants of defense systems. Previous studies have reported that there was an increase in lipid peroxidation in liver, kidney, brain, heart [67], pancreas [60], and erythrocytes [68] of diabetic rats. Patel et al. [69] suggested this elevation in hepatic MDA level might be due to high concentration of lipid, which was found in liver of diabetic rats, and resulted in the activation of NADPH dependent microsomal lipid peroxidation in liver.

The effects of long-term diabetes on the antioxidant enzymes in the rat liver have been reported. Selvan et al. [70] stated that hepatic SOD and CAT activities were decreased significantly in STZ-induced diabetic rats. Also, Chandramohan et al. [68] suggested that the decrease in the activities of hepatic SOD and CAT in diabetic rats may result in a number of deleterious effects due to the accumulation of superoxide anion radical and hydrogen peroxide. Furthermore, the decrease in the activity of CAT could result from inactivation by superoxide radical and glycation of the enzyme [60].

In the present work, the decreased activity of GPx in liver during diabetes mellitus may be attributed to the production of reactive oxygen species (ROS) such as superoxide $\left(\mathrm{O}_{2}^{-}\right)$, hydrogen peroxide $\left(\mathrm{H}_{2} \mathrm{O}_{2}\right)$, and hydroxyl radical $\left(\mathrm{OH}^{-}\right)$[71] . Similarly, previous investigator indicated that the hepatic GSH-Px activity of STZ-induced diabetic rats decreased significantly as compared to the normal control group [72].

The reduction in GSH was consistent with El-Shenawy and Abdel-Nabi [73] who reported that the hepatic and pancreas GSH decreased significantly in alloxan-diabetic mice. Chakraborty and Das [74] and Veerapur et al. [75] mentioned that the concentration of GSH significantly decreased in the liver of STZ-diabetic rats, and this decrease represented an increase in the utilization due to the oxidative stress. Also, the decrease in GSH levels could probably be due to decreased synthesis or increased degradation of GSH by oxidative stress as reported by Saravanan and Ponmurugan [76]. A decrease in the level of GSH in the liver [77], plasma [78], cardiomyocyte [79] and pancreas [80] have been reported in diabetic rats.

The prevention of oxidative stress by taurine was also reported in alloxan-induced type 1 diabetic [81]. Interestingly, taurine supplementation for 2 days later of STZ injection, prolonged survival in diabetic rats [82]. This observation indicates that taurine may confer resistance against some stresses induced by hyperglycemia, which may associate with the beneficial role against the complications. Administration of taurine protected the tissue damage produced by the acute sublethal dose of $\gamma$ irradiation in rats by decreasing oxidative stress [83].

The benefits of the taurine amino acid appears to be due to its various actions on cellular functions while toxicity seems relatively low, further studies are important to fill the gaps between animals and humans.

\section{References}

[1] Centers for Disease Control and Prevention. National Diabetes Fact Sheet, 2012. Atlanta, GA: Centers for Disease Control and prevention, US Department of Health 


\section{International Journal of Science and Research (IJSR) \\ ISSN (Online): 2319-7064}

Index Copernicus Value (2013): 6.14 | Impact Factor (2014): 5.611

and Human Services; 2012. http:// www.cdc.gov/diabetes/pubs/pdf/ndfs.

[2] Bergman M, Buysschaert M, Schwarz PEH, Albright A, Yach D. (2012). Diabetes prevention: global health policy and perspectives from the ground. Diab. Manage; 2:309-321.

[3] Kahn SE, Hull RL, Utzschneider KM. (2006). Mechanisms linking obesity to insulin resistance and type 2 diabetes. Nature; 444: 840-846.

[4] Pari L, Saravanan R. (2004). Antidiabetic effect of diasulin, a herbal drug, on blood glucose, plasma insulin and hepatic enzymes of glucose mretabolismhyperglycaemic rats. Diabetes, Obesity and Metabolism; 6(4): 286-292.

[5] Nammi S, Boini MK, Lodagala DS, Behara RBS. (2003). The juice of fresh leaves of Catharanthus rosesus Linn reduces blood glucose in normal and alloxan diabetic rats. BMC Complement Altern Med; 3: $1-4$.

[6] Kim SJ, Gupta RC, Lee HW. (2007). Taurinediabetes interaction: from involvement to Protection. Curr Diabetes Rev; 3 (3): 165-175.

[7] Belluzzi O, Puopolo M, Benedusi M, Kratskin I. (2004). Selective neuroinhibitory effects of taurine in slices of rat main olfactory bulb. Neuroscience; 124 (4): 929-944.

[8] Bouckenooghe T, Remacle C, Reusens B. (2006). Is taurine a functional nutrient? Curr Opin Clin Nutr Metab Care; 9(6): 728-33.

[9] El- Nahrawy, WAM, Heibashy MIA. (2011). Possible synergistic therapeutic role of taurine and curcumin on cerulean-induced acute pancreatitis in rats. J. Am. Sci.; 7(7): 485-95.

[10] Das J, Ghosh J, Manna P, Sil PC. (2008). Taurine provides antioxidant defence against $\mathrm{NaF}$ - induced cytotoxicity in murine hepatocytes. Pathophysiology; 15: 181-190.

[11] Zulli A. (2011). Taurine in cardiovascular disease. Current Opinion in Clinical Nutrition and Metabolic Care; 14 (1):57-60.

[12] Ito T, Schaffer SW, Azuma J. (2012). The potential usefulness of taurine on diabetes mellitus and its complications. Amino Acids; 42:1529-39.

[13]Lenzen S. (2008). The mechanisms of alloxan and streptozotocin-induced diabetes. Diabetologia; 51 (2): 216-226.

[14] Adil A, Wani, Sikdar-Bar M. (2013). Efficacy of taurine and garlic extract in modulating the alterations in haematological parameters induced by long-term exposure to copper sulphate in Clarias gariepinus. GERF Bulletin of Biosciences; 4(2): 1-10.

[15] Vinayagam R, Ramalingam S. (2013). Asiatic acid prevents lipid peroxidation and improves antioxidant status in rats with streptrozotocin-induced diabetes. Journal of Functional foods; 5: 77-87.

[16] Trinder P. (1969). Determination of glucose in blood using glucose oxidase with an alternative oxygen acceptor. Ann. Clin. Biochem; 6: 24-5.

[17] Rohlfing C, Connolly S, England J, Hanson S, Moellering C, Bachelder J, Little R. (2008). The effect of elevated fetal hemoglobin on $\mathrm{HbAlc}$ results: five common HbAlc methods compared to the IFCC reference method. Amer J Clin Path; 129:811-4.
[18]Finlay JWA, Dillard RF. (2007). Appropriate calibration curve fitting in ligand binding assays. AAPS J; 9(2):E260E267.

[19] Pulse S. (1972). Determination of Amylase activity in vitro. Methods Enzymol. Jouyban 2 Spectrofluorimetric; 97-101.

[20] Gubern G, Canalias F, Gella FJ. (1995). Determination of alpha-amylase activity, methods comparison and commutability study of several control materials. Clin Chem. Mar.; 41(3):435-8.

[21] Huijing F. (1970). A rapid enzymic method for glycogen estimation in very small tissue samples. Clin Chem Acta; 30: 567-572.

[22] Tietz NW. (1976). Fundamentals of clinical chemistry W.B. Sanuders Co., $3^{\text {rd }}$. Philadelphia, 47-52, 1211.

[23] Henry RJ. (1974). Clinical chemistry, principles and techniques, (2nd Ed). Harper and Row, Hagerstown MD. Lange medical publication. California; 819-831 pp.

[24] Gornall AJ, Bardawill CJ, David MM. (1949). Determination of serum proteins by means of the biuret reaction. J. Biol. Chem.; 177: 751-66.

[25] Allain CA, Poon LS, Chane CHG, Richmond W, Wu PC. (1974). Enzymatic determination of total cholesterol. Clin. Chem.; 20: 470-475.

[26] Burstein M, Scholnick HR, Morfin R. (1970). Rapid method for the isolation of lipoproteins from human serum by precipitation with polyanions. J. Lipid Res.; 11: 583-595.

[27] Wahlefeld AW, Bergmeyer HU. (1974). Methods of Enzymatic Analysis. 2 ${ }^{\text {nd }}$ edition, New York, Academic Press Inc. 1831-1835 pp.

[28]Frings CS, Dunn RT. Colorimetric method for determination total serum lipids based on the sulphopospho vanillin reaction. Am J Clin Pathol 1979; 53: 89-91.

[29] Newman DJ, Price CP. (2001). Tietz Fundamental of Clinical Chemistry, $5^{\text {th }}$ Ed., Burtis, C.A.\& Ashwood,E.R. (W.B.Saunders eds. Philadelphia USA). 414 pp.

[30] Ohkawa H, Ohishi W, Yagi K. (1979). Assay for lipid peroxides in animal tissue by thiobarbituric acid reaction. Anal. Biochem.; 95(2): 351-8.

[31] Beutler E, Duron O Kelly BM. (1963). Improved method for the determination of blood glutathione. J. Lab. Clin. Med.; 61: 882-888.

[32] Nishikimi M, Roa NA, Yogi K. (1972). The occurrence of superoxide anion in the reaction of reduced phenazine methosulfate and molecular oxygen. Biochem. Bioph. Res. Common.; 46 (2): 849-54.

[33] Aebi H. (1984). Catalase in vitro. Methods Enzymol.; 105: 121-126.

[34] Paglia DE, Valentine WN. (1967), Studies on the qualitative characterization of erythrocyte glutathione peroxidase. J. Lab. Clin. Med.; 70: 158-69.

[35] Oyedemi SO, Yakubu MT, Afolayan AJ. (2011). Antidiabetic activities of aqueous leaves extract of Leonotis leonurus in streptozotocin induced diabetic rats. J Med Plant Res.; 5 (1): 119-125.

[36] Lee SI, Kim JS, Oh SH, Park KY, Lee HG, Kim SD. (2008). Antihyperglycemic effect of Fomitopsis pinicola extracts in streptozotocin-induced diabetic rats. J. Med. Food; 11 (3):518-24.

[37] Zafar M, Naeem-UL-Hassan NS. (2010). Effects of STZInduced diabetes on the relative weights of kidney, liver and 


\section{International Journal of Science and Research (IJSR) \\ ISSN (Online): 2319-7064}

Index Copernicus Value (2013): 6.14 | Impact Factor (2014): 5.611

pancreas in albino rats: a comparative study. Int. J. Morphol.; 28(1):135-142.

[38] Ren XJ, Guan GJ,Liu G, Zhang T Liu GH. (2009). Effect of activin A on tubulointerstitial fibrosis in diabetic nephropathy. Nephrol.; 14(3):311-20.

[39] Heidari Z, Mahmoudzadeh-Sagheb H, Moudi BA. (2008). Quantitative study of sodium tungstate protective effect on pancreatic beta cells in streptozotocin-induced diabetic rats. Micron.; 39(8):1300-5.

[40] Anusuya N, Rajarathinam NI, Nungampakkam SM. (2013). Antidiabetic, antihyperlipidemic and antioxidant effect of ethanolic extract of Curcuma raktakantha J.K. Mangaly \& M. SABU on streptozotozin induced diabetic rats. International Journal of Pharmacy and Pharmaceutical Sciences; 5 (3): 201-206.

[41] The International Expert Committee (2009). International Expert Committee Report on the Role of the A1C Assay in the Diagnosis of Diabetes. Diabetes Care; 32(7): 1327-1334.

[42] Shirwaikar A, Rajendran K, Barik R. (2006). Effect of aqueous bark extract of Garuga pinnata Roxb. in streptozotocin-nicotinamide induced type-II diabetes mellitus. J. Ethnopharmacol.; 107: 285-90.

[43] Saleh AA. (2012). Effect of taurine and / or ginseng and their mixture on lipid profile and some parameters indicative of myocardial status in streptozotocin-diabetic rats. Journal of basic and applied zoology; 65, 267-73.

[44] Yadav R, Bhartiya JP, Verma SK, Nandkeoliar MK. (2013). The evaluation of serum amylase in the patients of type 2 diabetes mellitus, with a possible correlation with the pancreatic functions. J Clin Diagn Res.; 7(7):1291-4.

[45] Burski K, Ueland T, Maciejewski R. (2004). Serum amylase activity disorders in the course of experimental diabetes in rabbits. Vet. Med. Czech; 49(6): 197-200.

[46] Ragavan B, Krishnakumar S. (2006). Antidiabetic effect of $t$. arjuna bark extract in alloxan induced diabetic rats. Indian Journal of Clinical Biochemistry; 21 (2): 123-128.

[47] Kondetia VK, Kameswara RB, Dilip RM, Sampath KMT, Shaik SF, Ramesh BK, Chippada AR. (2010). Effect of Pterocarpus santalinus bark, on blood glucose, serum lipids, plasma insulin and hepatic carbohydrate metabolic enzymes in streptozotocininduced diabetic rats. Food and Chemical Toxicology; 48(5):1281-1287.

[48] Carneiro EM, Latorraca MQ, Araujo E, Beltra M, Oliveras MJ, Navarro M, Berna G, Bedoya FJ, Velloso LA, Soria B, Martin F. (2009). Taurine supplementation modulates glucose homeostasis and islet function. Journal of Nutritional Biochemistry; 20: 503-511.

[49]Higo S, Miyata S, Jiang QY, Kitazawa R, Kitazawa S, Kasuga M.(2008): Taurine administration after appearance of proteinuria retards progression of diabetic nephropathy in rats. Kobe J Med Sci; 54 (1): 35-45.

[50] Gavrovskaya LK, Ryzhova OV, Safonova AF, Matveev AK, Sapronov NS. (2008). Protective effect of taurine on rats with experimental insulin-dependent diabetes mellitus. Bull Exp Biol Med; 146 (2): 226-228.

[51] Kim KS, Oh da H, Kim JY, Lee BG, You JS, Chang KJ, Chung HJ, Yoo MC, Yang HI, Kang JH, Hwang YC, Ahn KJ, Chung HY, Jeong IK. (2012). Taurine ameliorates hyperglycemia and dyslipidemia by reducing insulin resistance and leptin level in Otsuka Long-Evans Tokushima fatty (OLETF) rats with long-term diabetes. Exp Mol Med.; 44(11):665-73.

[52] Kumarappan CT, Thilagam E, Vijayakumar M, Subhash C. (2012). Mandal Modulatory effect of polyphenolic extracts of Ichnocarpus frutescens on oxidative stress in rats with experimentally induced diabetes. Indian $\mathrm{J}$ Med Res. Nov; 136(5): 815-821.

[53] Irshaid F, Mansi K. (2009). The effect of methanol extract derived from Urtica pilulifera leaves on some hematological and biochemical parameters of diabetic rats. Res. J. Biol. Sci.; 4(6): 675-81.

[54] Ahn HR, Min-Ho S, Hae-Sung N, Kyeong-Soo P, YoungHoon L, Seul-Ki J, Jin-Su C, Sun-Seog K. (2014). The association between liver enzymes and risk of type 2 diabetes: the Namwon study. Diabetology \& Metabolic Syndrome; 6:14.

[55] Raju SM, Raju B. (2010). Illustrated medical biochemistry. 2nd Edition. Jaypee Brothers Medical Publishers 1td, New Delhi, India, 645pp.

[56] Daisy P, Vargese L, Priya CE. (2009). Comparative studies on the different leaf extracts of Elephantopus scaber L. on STZ-induced diabetic rats. European J. Scientific Research; 32: 304-13.

[57] Turner HE, Wass JAH. (2007). Diabetic Eye Disease. In: Oxford Handbook of Diabetes, edited by Turner HE and Wass JAH. New York: Oxford University Press, 30-40 pp.

[58]Zhang FF, Zhang YM, Men XL, Zhao LJ, Kong XY, Dong SY. (2010). Effects of taurine on hemorheology of rats with type 2 diabetes. Zhongguo Ying Yong Sheng Li Xue Za Zhi; 26(4):474-6.

[59] Shivanand KG, Manjunath ML, Jeganathan PS. (2012). Lipid profile and its complications in diabetes mellitus. International Journal of Biomedical and Advance Research, 03 (10):775-780.

[60] Bagri P, Ali M, Aeri V, Bhowmik M, Sultana S. (2009). Antidiabetic effect of Punica granatum flowers: Effect on hyperlipidemia, pancreatic cells lipid peroxidation and antioxidant enzymes in experimental diabetes. Food Chem. Toxicol.; 47: 50-4.

[61] Heibashy MIA. (2000). Hypolipidemia effect of taurine and L-carnitine on rats fed a high cholesterol diet. J. Union Arab Biol. Cairo; 14(A), 11-23.

[62] Chang YY, Chou CH, Chiu CH, Yang KT, Lin YL, Weng WL, Chen YC. (2011). Preventive Effects of Taurine on Development of Hepatic Steatosis Induced by a HighFat/Cholesterol Dietary Habit. J. Agric. Food Chem.; $59,450-457$.

[63] Yang SF, Bor-Show T, Kuo-Tai Y, Yuan-Chao H,YuanYen C, Chi-Ho C, Shih-Guei F, Yi-Chen C. (2010) Taurine alleviates dyslipidemia and liver damage induced by a high-fat/cholesterol-dietary habit. Food Chemistry; 120 156-162.

[64] Prangthip P, Surasiang R, Charoensiri R, Leardkamolkarn V, Komindr S, Yamborisut U. (2013). Amelioration of hyperglycemia, hyperlipidemia, oxidative stress and inflammation in streptozotocin-induced diabetic rats fed a 


\section{International Journal of Science and Research (IJSR) \\ ISSN (Online): 2319-7064}

Index Copernicus Value (2013): 6.14 | Impact Factor (2014): 5.611

high fat diet by riceberry supplement. Journal of Functional Foods; 5(1): 195-203.

[65] Vinik AI, Maser RE, Mitchell BD, Freeman R. (2003). Diabetic autonomic neuropathy. Diabetes Care; 26: 1553-79.

[66] Madsen-Bouterse SA, Kowluru RA. (2008). Oxidative stress and diabetic retinopathy: pathophysiological mechanisms and treatment perspectives. Rev Endocr Metab Disord.; 9: 315-27.

[67] Kumar G, Banu S, Murugesan AG. (2009). Influence of Helicteres isora administration for diabetes mellitus: Its effect on erythrocyte membrane and antioxidant status. Food Chem. Toxicol.; 47: 1803-9.

[68] Chandramohan G, Al-Numair KS, Pugalendi KV. (2009). Restoration of altered plasma, erythrocyte and liver antioxidant levels by 3-hydroxymethyl xylitol in streptozotocin-diabetic rats. Int. J. Integr. Biol.; 5: 176181.

[69] Patel SS, Shah RS, Goyal RK. (2009). Antihyperglycemic, antihyperlipidemic and antioxidant effects of Dihar, a polyherbal ayurvedic formulation in streptozotocin-induced diabetic rats. Ind. J. Exp. Biol.; 47: 564-70.

[70] Winiarska K, Szymanski K, Gorniak P, Dudziak M, Bryla J. (2009). Hypoglycaemic, antioxidative and nephroprotective effects of taurine in alloxan diabetic rabbits. Biochim.; 91:261-70.

[71] Kaleem M, Asif M, Ahmed QU, Bano B. (2006). Antidiabetic and antioxidant activity of Annona squamosa extract in streptozotocin-induced diabetic rats. Singapore Med. J.; 47: 670-5.

[72] Firdaus M, Astawan M, Muchtadi D, Wresdiyati T, Waspadji S, Karyono SS. (2010). Prevention of endothelial dysfunction in streptozotocin-induced diabetic rats by Sargassum echinocarpum extract. Med. J. Indones; 19: 32-5.

[73] El-Shenawy NS, Ismail MA. (2006). Hypoglycemic effect of Cleome droserifolia ethanolic leaf extract in experimental diabetes, and on non-enzymatic antioxidant, glycogen,thyroid hormone and insulin levels. Diabetologia Croatica; 35 (1):15-22.

[74] Chakraborty U, Das H. (2010). Antidiabetic and antioxidant activities of Cinnamomum tamala leaf extracts in STZ-treated diabetic rats. Global J. Biotechnol. Biochem.; 5(1): 12-8.

[75] Veerapur VP, Prabhakar KR, Parihar VK, Bansal P, Srinivasan KK, Priyadarsini KI. (2010). Antidiabetic, hypolipidaemic and antioxidant activity of Dodonaea viscosa aerial parts in streptozotocin-induced diabetic rats. International Journal of Phytomedicine; 2: 59-70.

[76] Saravanan G, Ponmurugan P. (2012). Antidiabetic effect of S-allylcysteine: Effect on Thyroid hormone and circulatory antioxidant system in experimental diabetic rats. Journal of diabetes and its Complications; 26 (4): 280-5.

[77] Sancheti S, Shruti S, Mayur B, Sung-Yum S. (2010). Antihyperglycemic, antihyperlipidemic, and antioxidant effects of Chaenomeles sinensis fruit extract in streptozotocin-induced diabetic rats. European Food Research and Technology; 231(3): 415-421.

[78] Makni M, Fetoui H, Gargouri NK, Garoui EM, Zeghal N. (2011). Antidiabetic effect of flax and pumpkin seed mixture powder: effect on hyperlipidaemia and antioxidant status in alloxan diabetic rats. Journal of diabetes and its Complications; 25 (5): 339-45.

[79] Ghosh S, Simon T, Howard L, Thomas P, Ding A, Dake Q, Mohammed AA, Brian R. (2004). Increased efflux of glutathione conjugate in acutely diabetic cardiomyocytes. Can. J. Physiol. Pharmacol.; 82: 879-887.

[80] Babujanarthanam R, Kavitha P, Mahadeva RU, Pandian MR. (2011). Quercitrin a bioflavonoid improves the antioxidant status in streptozotocin: induced diabetic rat tissues. Molecular and Cellular Biochem.; 358:121-9.

[81] Di Leo MA, Santini SA, Gentiloni Silveri N, Giardina B, Franconi F, Ghirlanda G. (2004). Long-term taurine supplementation reduces mortality rate in streptozotocininduced diabetic rats. Amino Acids; 27:187-191.

[82] Monira AA, Manal HE, Amina MAT, Mamdouh MA, Anisa SM. (2015). Evaluation of Taurine Role on Some Biochemical and Histological Alterations in $\gamma$ - Irradiated Rats. Int. J. Pharm. Sci. Rev. Res.; 30(1): 263-271.

[83] Selvan VT, Manikandan L, Senthil KGP, Suresh R, Kakoti BB, Gomathi P. (2008). Antidiabetic and antioxidant effect of methanol extract of Artanema sesamoides in streptozotocin-induced diabetic rats. International Journal Applied Research in Natural Products; 1(1): 25-33. 